\title{
Living Conditions in Retirement Homes in the Czech Republic and Austria from Seniors' Point of View
}

\author{
L. Mathová ${ }^{1}$ and P. Formánková2,* \\ ${ }^{1}$ University of South Bohemia in České Budějovice, Faculty of Health and Social Studies, Department of \\ Social Work, Czech Republic \\ ${ }^{2}$ University of South Bohemia in České Budějovice, Faculty of Health and Social Studies, Department of \\ Fields of Law, Management and Economics, Czech Republic
}

\begin{abstract}
Senior citizens generally face more challenging life situations than other people (death of people close to them, deteriorating health, loss of social status, leaving home, etc.) - even multiple such situations at one time - and must cope with them. The focus of this report is one of these situations: the life of senior citizens in a retirement home, which is a type of residential social services. OBJECTIVE: The objective of this research was to map the living conditions of seniors living in 1 retirement home in the Pisek region (Czech Republic) and in 1 retirement home in the Innsbruck region (Austria). METHODS: The enquiry method was chosen for the research. A semi-standardised interview with 40 seniors was carried out as part of routine data collection. The topics of the interview were compiled as to cover areas related to residential standards, eating, economic situation, maintaining of social contacts, use of free time and assessment of health care. RESULTS: The research showed that both Czech and Austrian seniors assess their living conditions in the home as good. The respondents gave positive feedback on the clean environment, health and nursing care and the rate of participation in events organised in the homes. What the seniors found positive is maintaining social contacts and they prefer the availability of the above-standard service provided in the home. CONCLUSION: The research also showed that the reason for moving into the retirement home is primarily health problems and the related fear of compromised independence.
\end{abstract}

Keywords: Retirement home, living conditions, senior, residential care, social services.

\section{INTRODUCTION}

Retirement homes are residential social facilities providing a residential form of senior care [1]. These social care homes provide services aimed at supporting human independence and creating conditions for a dignified and active life. Seniors in residential care do not make use of a uniform service package. The basic service is accommodation and usually eating [2]. Depending on individual needs, seniors can also use other services such as help with routine care of oneself and self-sufficiency related tasks, help with the household and a wide range of social therapy activities [1]. The homes support seniors' participation in social life. These homes create conditions for voluntary activities for senior citizens depending on their abilities and interests with the aim of creating the right content for their lives [3]. The operator of retirement homes is also obliged to provide health care for clients through ambulant care [1]. Each country and/or founder of a retirement home lays down different terms and conditions for acceptance of seniors into the retirement home. In the Czech Republic, for instance, every retirement home keeps its own

*Address correspondence to these authors at the University of South Bohemia in České Budějovice, Faculty of Health and Social Studies, Department of Social Work, Jírovcova 24, 37004 České Budějovice, Czech Republic; Tel: +420 38903 7664, +420 777297 740; E-mails: motlova@zsf.jcu.cz, Formankova.p@seznam.cz application records. There is no fixed criterion which would determine the terms and conditions under which the senior is entitled to stay in a home [4]. On the contrary, in Austria the terms for evaluating applicants for acceptance into the retirement home are clearly set - e.g. the minimum requirement is 120 -hour care within one month etc. [5].

The probability that the senior will need help with routine tasks of everyday life increases with age. Physical capabilities demarcating individual experience affect one's ability to perform a number of activities, determine the scope and quality of communication with other people and have an impact on one's individuality, psychological wellbeing and satisfaction with life. The independence of seriously ill, immobile and the "oldest old" citizens in particular entails restrictions of personal control over one's life and delegates them to others family members or institutions [6].

The reasons why elderly people move into retirement homes vary and are often mixed. They for example leave when loneliness becomes unbearable, when their children cannot or do not want to take care of them and often also when they simply no longer manage safely at home [3]. In the majority of cases they are aware that this will last until the end of their lives. Leaving one's home means saying goodbye to the past, to everything that has formed one's life. 
Entering a retirement home is a serious event in seniors' lives and even more taxing when they are not ready for it. Those who were able to make ample preparations for leaving for a retirement home and made the decision themselves have an easier time integrating into life there [7]. The model where the senior chooses from a great variety of homes the one which best fits their needs and where social and health care can be provided later on is ideal [8].

Every change is demanding and the ability to adapt decreases with age. In many scenarios, institutional care is the optimum outcome for the issue with no solution: the senior's stay at his/her own household [3]. Senior care must be focused primarily on satisfying seniors' needs and solving their problems [9]. Major instruments for prevention of the negative impacts of institutional care include an interest in individual human needs, the structure of which was prepared in the 1940 s by A. H. Maslow as part of the concept of humanistic and trans-personal psychology, further developed by Maslow's contemporaries V. I. Frank and C. A. Rogers. They created the theory of a personality's motivation system - a hierarchy of needs [10]. The environment in which we live strongly affects the quality of individual. For this reason, it is important that one's stay in a retirement home ensures privacy, independence and offers seniors the possibility of social contact [2]. The overall care must be based not only on the evaluation of bodily changes, but also the understanding of the person as a comprehensive human being. Also, changes to the way we experience things, to social roles and life perspectives must be kept in mind [11]. The criterion for evaluating life quality, for provision of care, the environment, etc. must be the seniors themselves [9].

\section{METHOD}

\subsection{Data Collection and Realization of Research}

Qualitative research was chosen for data collection. The enquiry method and a semi-standardised interview was applied. The semi-controlled interview was conducted face to face with 40 seniors. The first research sample was a group of 20 senior citizens living in a retirement home in the Písek region (Czech Republic). The second research sample comprises 20 senior citizens living in a retirement home in the Innsbruck region in Tyrol, Austria. The interview touched on seven areas and included 38 questions. Answers were recorded into a designated file. Thanks to the information obtained from Czech and Austrian respondents, attention could be paid to possible changes in opinions of both monitored groups, allowing a comparative data collection analysis.

The research was conducted from 30 Oct 2011 to 10 Dec 2011 in 1 retierement home in the Czech Republic and in 1 retirement home in Austria in direct cooperation with the seniors living in those homes. Respondents were selected by the staff of the facility through purpose-based quotas. For the sake of validity of research results, the research sample excluded respondents with cognitive function disorders. The interview took 45-60 minutes.

\subsection{Research Sample}

The basic sample counted 240 senior citizens living in 2 retirement homes in the Písek and Innsbruck regions. The sample counted 40 respondents living in the retirement homes. 2 criteria were applied for respondent selection: consent with participation in the research, an age of 60 years or more and residency in the retirement home. None of the respondents had health conditions requiring continuous care. The sample of Czech respondents included 12 women and 8 men; the sample of Austrian respondents included 14 women and 6 men. As for the age structure, the youngest senior was 61 and the oldest 93 years old. The average age of respondents was 82.5 years (for more details see Table 1).

\section{Table 1: Sample Characteristic}

\begin{tabular}{|c|c|c|}
\hline & $\begin{array}{l}\text { Number of Czech } \\
\text { respondents }\end{array}$ & $\begin{array}{l}\text { Number of Austrian } \\
\text { respondents }\end{array}$ \\
\hline Total & 20 & 20 \\
\hline \multicolumn{3}{|l|}{ Sex } \\
\hline women & 12 & 14 \\
\hline men & 8 & 6 \\
\hline \multicolumn{3}{|l|}{ Age } \\
\hline $60-74$ years & 9 & 6 \\
\hline $75-89$ years & 9 & 12 \\
\hline $90+$ & 2 & 2 \\
\hline \multicolumn{3}{|c|}{ Duration of stay in retirement home } \\
\hline up to 1 year & 4 & 5 \\
\hline $1-2$ years & 6 & 6 \\
\hline $3-5$ years & 7 & 6 \\
\hline $5+$ years & 3 & 3 \\
\hline
\end{tabular}




\section{RESULTS}

\subsection{Results of Relationship Respondents to Retirement Home}

Table 2 shows that the most frequent reason for leaving for the residential home was the need for everyday care. This answer was provided by 6 out of 20 respondents living in the retirement home in the Czech Republic. 4 respondents stated that the reason was an effort to make space for younger family members. 3 seniors were afraid of a decline in their health and feared that there would be no free place for them later. This reason was mentioned by 7 out of 20 Austrian respondents. 5 respondents left for the retirement home due to the need for everyday care and 3 respondents stated that family members could no longer take care of them. The remaining part of the respondents in both groups stated equally the following reasons: they did not want to be a burden to their family members, felt lonely and were not provided social services at their place of residence which would allow them to stay at home.

Table 2: Reason for Leaving Home for the Retirement Home

\begin{tabular}{|c|c|c|}
\hline & $\begin{array}{c}\text { Number of } \\
\text { Czech } \\
\text { respondents }\end{array}$ & $\begin{array}{c}\text { Number of } \\
\text { Austrian } \\
\text { respondents }\end{array}$ \\
\hline \hline Total & $\mathbf{2 0}$ & $\mathbf{2 0}$ \\
\hline need for everyday care & 6 & 5 \\
\hline $\begin{array}{c}\text { fear of compromised health } \\
\text { family members }\end{array}$ & 3 & 7 \\
\hline $\begin{array}{c}\text { family members could not } \\
\text { ensure care }\end{array}$ & 2 & 3 \\
\hline feeling of loneliness & 2 & 2 \\
\hline $\begin{array}{c}\text { service was not provided in } \\
\text { place of residence }\end{array}$ & 1 & 0 \\
\hline $\begin{array}{c}\text { make space for younger family } \\
\text { members }\end{array}$ & 4 & 1 \\
\hline
\end{tabular}

The results also revealed (see Table 3) that 10 Czech and only 2 Austrian seniors chose the particular retirement home because it offered a free place. On the contrary, 6 Czech and 15 Austrian respondents chose the home because it was the closest to their original place of residence and family members. The remaining 4 Czech and 3 Austrian respondents left for the home because they had received a positive reference from persons close to them.
Table 3: Reason for Choosing the Particular Retirement Home

\begin{tabular}{|c|c|c|}
\hline & $\begin{array}{c}\text { Number of } \\
\text { Czech } \\
\text { respondents }\end{array}$ & $\begin{array}{c}\text { Number of } \\
\text { Austrian } \\
\text { respondents }\end{array}$ \\
\hline \hline Total & $\mathbf{2 0}$ & $\mathbf{2 0}$ \\
\hline a place was vacant & 10 & 2 \\
\hline closest to original home & 6 & 15 \\
\hline $\begin{array}{c}\text { positive word of mouth } \\
\text { about retirement home }\end{array}$ & 4 & 3 \\
\hline
\end{tabular}

Respondents from both groups mostly stated (9 Czech and 15 Austrian) that the home is located in the same town where they were living all their lives. 6 Czech and 3 Austrian respondents are remote from their place of residence up to $20 \mathrm{~km}$ and fewest respondents ( 5 Czech and 2 Austrians) more than $20 \mathrm{~km}$ from their original home and those close to them.

A total of 15 out of 20 Czech and 17 out of 20 Austrian respondents said they would not return to their original home. They reported that they have already become used to life in the home, have certain services provided, nursing care is available to them, they maintain constant social contact with the surroundings and leisure-time activities are at hand. The seniors also reported that they could no longer take care of themselves in their home environment and that care could not be provided by their family members. Some seniors said they have nowhere to go back to. The remaining respondents (5 Czech and 3 Austrian) said they would return to their home environment, because they have not adapted to living in an institutional environment.

9 Czech and 11 Austrian respondents stated that life in the retirement home is as good as in their home environment. An interesting finding is that more than $1 / 3$ of respondents (8 Czech and 6 Austrian) evaluate the quality of life in the retirement home better than it had been in the conditions of their original home. Even though the number of respondents who evaluate their existing life in the home as worse is relatively small ( 3 Czech and 3 Austrian), these persons represent the potentially "problematic" group to which increased attention must be paid. Their desires and/or homesickness may result in health problems in terms of their physical as well as mental condition. All respondents said that their living conditions in the home might improve. They wish that more one-bed 
rooms would be set up and they would spend their free time in a way which makes more sense to them. Czech respondents would also appreciate volunteers coming and talking with them.

\subsection{Results of Respondents' Economic Situation}

The research showed that the respondents evaluate their economic situation positively in both groups. 3 respondents evaluated their economic situation as excellent (1 Czech and 3 Austrians), 20 respondents as good (9 Czechs and 11 Austrians) and 10 respondents as average (4 Czechs and 6 Austrians). 7 respondents evaluated their economic situation as rather bad (3 Czechs and 4 Austrians).

All respondents from both groups addressed know how much they contribute for the accommodation and care provided to them. 16 Czech and more than half (11) of Austrian respondents said that their regular income is sufficient to finance their stay in the home (i.e. their relatives do not have to contribute and/or they need not use their savings to pay for accommodation and care). The remaining 4 Czech and 9 Austrian respondents must finance their stay from their life savings or with financial help from their families.

The research showed that 12 Czech and 15 Austrian respondents have no fear of possible changes in payments for accommodation and health care. 5 Czech and 5 Austrian respondents have partial fears and 3 respondents fear this entirely. When comparing the data from the previous two paragraphs, we can deduce that among seniors who evaluate their economic situation rather positively and are able without major difficulties to pay the costs of their stay in the home, there are fears about a possible disproportion between their future income and expenses (i.e. mostly increased expenses).

\subsection{Results of Satisfaction with Quality of Living}

It was found that the respondents evaluate the residential quality in both homes very positively. It can be deduced from the evaluation that the residential quality in the Austrian facility is higher, because 15 out of 20 Austrian respondents are "very satisfied" with the quality and the remaining 5 "quite satisfied". On the contrary, 1 Czech respondent is only "partially satisfied", 15 respondents are "quite satisfied" and 4 respondents are "very satisfied".

Before moving into the retirement home, all 40 persons had the chance to decide if they wished to have a one-bed room or a room with more beds. The respondents from both groups $(11$ Czech and 16 Austrian) mostly said that they stay in a one-bed room and the remaining 9 Czech and 4 Austrian respondents said they live in a two-bed room. None of the respondents is staying in a room with more than two beds.

The text below captures the answers of only those respondents (8 Czech and 4 Austrian) who share a room with another person. Most respondents (6 Czech and 4 Austrian) said they have a positive and friendly relationship with that person. The remaining 2 Czech respondents have a neutral relationship with the roommate. The research showed that seniors in the institution have the possibility to move out from a room with a person they do not get on well with.

Based on the answers from the respondents, all respondents evaluated the change in their life after moving into the retirement home in a rather positive light. As people mostly perceive these changes in a cumulative way, the frequency of answers by the respondents was also recorded. What the respondents stated most often (18 Czech and 17 Austrian respondents) as a positive fact was the maintaining of social contacts, organising of big events and celebrations in which hardly any respondent had participated in his/her natural environment before, as 16 Czech and 19 Austrian respondents stated. Also, 15 Czech and 18 Austrian respondents appreciated the possibility of choosing from other leisure-time activities. For more than half of the respondents $11 \mathrm{Czech}$ and 12 Austrian) the availability of above-standard service directly onsite (hairdresser, pedicure) is a positive thing. The respondents also stated negative things they noticed after arriving in the retirement home. The biggest of such negatives (for 16 Czech and 14 Austrian respondents) was the loss of privacy and a changed daily regime. Some respondents feel they are less useful compared with their natural home environment where they were, for example, taking care of the garden, the household and/or their grandchildren, as 8 Czech and 5 Austrian respondents reported.

The results show that 13 out of 20 Czech and 15 out of 20 Austrian respondents have the possibility of deciding themselves their daily regime in the retirement home (mostly those who need minimal help with tasks and are therefore substantially less dependent on the staff). They do not have to strictly follow the regime of getting up early in the morning, taking care of personal 
hygiene, having breakfast, etc. They however still try to accommodate to the daily schedule in the retirement home, so they adapted their daily regime. These respondents stated that they have the possibility of getting up later, having breakfast as they want, etc. The remaining respondents (7 Czech and 5 Austrian) are, on the contrary, more dependent on the help of another person and their regime is adapted to the schedule of the retirement home staff.

The respondents from both groups (17 Czech and 16 Austrian) mostly stated that they are satisfied with eating in the home. Both groups were positive about the possibility to chose from more meals. They reported that they have enough fruits and vegetables and gave positive feedback on how their diet is taken into account. The remaining 3 Czech and 4 Austrian respondents are dissatisfied, however. These dissatisfied respondents said they would not prefer rice and pasta as the side dish, they do not like the yoghurt served for breakfast and dislike some meals which are too salty and spicy.

Some respondents felt that harm was caused to them by the staff (2 Czech and 1 Austrian) and roommates (2 Czech, 1 Austrian respondent) rather than from their family members (mostly for property reasons), as reported by 5 Czech and 3 Austrian respondents. If they are treated badly by the staff, it is not a failure of the system, but rather a failure of individuals in the home. The remaining 11 Czech and 15 Austrian respondents did not state this negative experience.

\subsection{Results of Respondents' Satisfaction with Health Care}

Most respondents (15 Czech and 8 Austrian) are satisfied with the health care provided to them. 3 Czech and 10 Austrian residents even said they are very satisfied. This contradicts the remaining 1 Austrian respondent who is partially satisfied and 2 Czech and 1 Austrian respondents who are generally dissatisfied. All respondents from both groups said that a satisfaction poll is conducted in the retirement home on a regular basis in which satisfaction with the service offered is evaluated.

The results of the poll show clearly that the staff providing care was evaluated by the respondents as very good. It can be deduced from the evaluation that satisfaction with caring staff in the Austrian home is greater, because 15 Austrian respondents are very satisfied with the staff, 3 are generally satisfied and 2 partially dissatisfied. On the other hand, 9 Czech respondents are only generally satisfied, 8 are very satisfied and 2 partially satisfied. 1 Czech resident is generally dissatisfied.

When comparing the frequency of seeing a doctor in the homes, there is a clear difference between the Czech and Austrian environment. If, for most Austrian respondents, the standard is a regular visit of a family doctor every two weeks ( 13 senior residents are visited by the doctor once a week and 3 respondents once in two weeks), then for the majority of Czech respondents it is common to see the doctor once per month or even less often (once per month for 7 respondents and less than once per month for 9 respondents). The Czech respondents also said in the interviews that the doctor visits them when they need (also Austrian residents said that the doctor would visit them when they need).

\subsection{Results of Residents' Satisfaction with Maintaining Social Contacts}

The research showed that most respondents (14 Czech and 17 Austrian) are satisfied with the frequency of visits by their relatives. On the contrary, 6 Czech and 3 Austrian respondents are not satisfied.

Most family members visit their elderly family in the retirement home several times per week, as 9 Czech and 13 Austrian respondents said. 6 Czech and 5 Austrian respondents are visited once in two weeks. 3 Czech and 1 Austrian respondent said their family members come less than once per month and only 2 Czech and 1 Austrian seniors are visited by their relatives once per month. All 40 respondents addressed said they have enough privacy during the visits and can talk with the visitor about any topic.

As several persons often come to see their elderly family members in the retirement home at once (combinations of people), the text quantifies the frequency of respondents' answers. The most frequent visitors to the residents are their family members, as 18 Czech and 19 Austrian respondents said. 13 and 17 Austrian respondents said they are visited by persons close to them (friends). Church volunteers are visiting 16 Austrian seniors.

The research showed further that 12 Czech and 13 Austrian respondents leave the home for several days to spend time with their family, for instance during Christmas or other holidays or during their relatives' vacation. The remaining 8 Czech and 7 Austrian 
respondents do not leave the home - some have nowhere to go or no longer have family members left.

It was found that 15 out of 20 Czech and 18 out of 20 Austrian respondents noticed after moving into the retirement home that the interest in them among their family members faded, while 5 Czech and 2 Austrian respondents do not feel this. They believe that a decline in interest from their family was caused by property disputes (e.g. giving property to one child, etc.).

The results show that 17 Czech and 18 Austrian respondents like very much to meet other residents in their free time. Only 3 Czech and 2 Austrian respondents said they have no need to communicate with other residents of the home.

\subsection{Results of Spending of Free Time}

Regarding the way the residents spend their free time, no major differences between the two groups can be found. The reason is that they often combine their activities. The seniors spend most of their time watching TV, going for a walk in the surroundings, doing crossword puzzles, reading books and magazines, doing handicrafts and other similar activities. It cannot be clearly determined from the research which leisure time activities are most and least popular among the residents. Every senior prefers different activities based on his/her hobbies.

It was found that 11 out of 20 Czech and 17 out of 20 Austrian respondents attend some of the events organised in the retirement home. On the contrary, 9 Czech and 3 Austrian respondents do not find the activities offered appealing or they do not attend them for reasons of poor health. The respondents from both groups said that a variety of activities are offered on a daily basis. The Czech seniors said that they can go to a workshop, do physical exercise, attend religious functions and go on trips. Their Austrian counterparts visit workshops, do physical exercise, train their memory, attend knowledge competitions, go to singing or painting lessons, attend lectures and go on trips or attend religious functions.

The results show that 13 Czech and all 20 Austrian respondents are satisfied with the leisure-time activities on offer. On the contrary, 7 Czech respondents are dissatisfied, saying that they would like to take care of the garden, attend dance lessons, lectures or seminars.

\section{DISCUSSION}

The results prepared by the authors show that almost half of the Czech respondents applied for the retirement home for a reason other than not being able to take care of themselves (see Table 2). The cause they mentioned was the need to make space for younger family members or a feeling of Ioneliness. These facts reflect the claim of Klevetová and Dlabalová [11] that in today's society there is a growing trend of separated life between generations. Members of the generation of grandparents live independent lives, but also in solitude.

Interesting are the opinions of respondents about the reasons they chose the particular retirement home. Most Czech residents chose the retirement home because it offered a free place. The Austrian seniors stated that they live in the particular home because it was the closest to their original place of residence, their family members and friends (see Table 3 ). This fact corresponds with the findings about the share of residents in the retirement homes tested where only 9 Czech but 15 Austrian seniors living in a residential retirement home are close to their original home. Based on the authors' own experience and available literature, the authors add that this is caused by the different coverage of retirement homes in two countries. Evidence of this is provided also by Glosová [2] who says that unlike the Czech Republic, smaller residential units in different parts of towns and cities are now preferred in Austria. This way, retirement homes are assigned to seniors in the same neighbourhood where their original place of residence was. It is then easier for the residents in the retirement home to maintain social contact with their environment.

The authors of the report also say that diverse factors affect different aspects of living conditions of the residents. Based on the results, they believe that the biggest factors are the duration of stay in the retirement home, age, health condition and frequency of visits of their family members and friends. Respondents living in the retirement home for more than five years and aged over 75 , with regular visits by their relatives and friends were more satisfied probably because they have already adapted to the conditions in the home. The research found, among other things, that out of the total of 40 respondents, 32 said they would not return to their original home. This correlates with the opinion of the authors that for many seniors is their stay in the retirement home a great relief. Here they are freed from 
many everyday worries and quality services are provided to them, ranging from eating and accommodation to a selection of leisure-time activities and nursing and health care.

A very interesting finding is that the respondents evaluate their economic situation rather positively in both groups. The authors however note that this finding is very surprising given the generally declared poor financial situation of seniors. The respondents said that they are still financially supporting their family members. These results correlate with the conclusion of the study by Klevetová and Dlabalová [11] according to which the majority of grandparents want to support financially their children and grandchildren, often at the expense of their own needs. They expect love, understanding and often also gratitude.

The results also point to diverse funding of the social services in both countries. 16 out of 20 Czech respondents said their regular income is sufficient for covering the expenses of their stay (i.e. without financial contribution of relatives and without having to use their savings to fund their stay). What the respondents see as a negative thing is that they need to hand in the full social care contribution to the retirement home. In the Czech Republic the client pays the cost of accommodation and food from his/her pension and the payment for care is determined so as to match the social contribution granted to the client [1]. Out of the 20 Austrian respondents only 11 said that their income is sufficient to finance their stay and services in the retirement home (this means, again, without having to spend their savings or require funding from relatives). The remaining 9 Austrian respondents must finance their stay from their savings or with the financial help of their families. Almost all Austrian respondents view it as positive that their 13th and 14th pensions (which do not exist in the Czech Republic) and $20 \%$ of their social care contribution is left for them. In Austria the funding is provided either by the client (savings, money from sale of assets or property, securities, etc.) or - where they are entitled to social support - their stay is funded from the pension insurance scheme. The federal state is entitled to a contribution from the family if the senior left a portion of his/her property to someone from the family within 30 years prior to retiring (in Tyrol, pursuant to federal state law) [5].

It was found that seniors evaluate their living conditions as good. 20 respondents said that they enjoy the same comfort as in their original home environment and 14 respondents even enjoy higher comfort. It can be noted that no large investments are needed to improve the quality of life for the seniors, with the exception of building more one-bed rooms. On the contrary - it is often a matter of such details as adjustment of one's daily regime and the possibility of spending free time in a way which makes sense for the residents. The Czech respondents would welcome volunteers coming to visit them and fill the gaps in their day. The research showed, among other things, that with growing dependence on the help of another person, the capacity to make decisions about one's own regime drops. These results correspond with the belief of Sýkorová [6] who says that while self-sufficient elderly people understand autonomy as control and independent decision-making and see themselves as competent persons, the caretakers reduce their control over their lives to the ability of personal care only. They view dependent seniors as ones unable and not entitled to make independent decisions. Interaction patterns resting upon the expected incompetence of seniors by others actually weakens their autonomy and strengthens dependent behaviour. Motlová [12] mentions in her research that seniors see disadvantages of the retirement home mostly in the need to adapt to a certain order in the home. Pichaud and Thareauová [17] emphasize that the most significant indicator for the quality of life of seniors is how much independence the residential retirement home leaves for the residents.

From the substantially higher frequency of visits to the doctor among Austrian residents it can be deduced that this care has the nature of significantly higher preemptive care and can also contribute to timely identification of serious diseases, timely start of treatment and better prospects for recovery. Based on the statements of the respondents, we can say that the seniors in Czech institutions miss the former general practitioner they were used to. A number of retirement homes have a contract with only one doctor who provides care to almost all residents in the home. The respondents said that they had freedom in choosing their doctor. They were however aware that the former doctor they were used to has his/her office far from the retirement home and it would be complicated to visit that doctor. In Austria the seniors still retain their home doctor in the retirement home.

It can be generally said that respondents living in the retirement home are satisfied with the frequency of visits, as reported by 31 out of 40 respondents. 16 Austrian and only 9 Czech seniors are visited not only 
by their relatives, but also by persons close to them. A major point in which the two countries differ is volunteers from the church coming to visit the residents. These results correspond with the conclusion of Motlová [12] who says that almost half of Czech seniors have lost contact with friends and people of the same age after leaving for a retirement home. It is however important to note that social support is among the factors contributing to keeping or stabilising the quality of life of elderly people [3]. The authors believe that the results reflect the fact that most Austrian clients are placed in a home situated as close as possible to their original place of residence. This allows relatives and friends to visit them more frequently.

Based on what the respondents stated, we can assume that satisfaction among seniors with the activities in the retirement home is affected by the duration of the stay in the home and primarily by the degree of self-sufficiency. With growing dependence on care, dissatisfaction with the activities offered is also growing. It must be noted that activities are intended mostly for independent seniors, so ways should be found for spending leisure time also for seniors confined to their bed. Based on the results, it can be noted that Austrian seniors have a choice of a wider range of activities than their Czech counterparts. All 40 seniors said that regular cultural events are organised in their home (e.g. during various holidays or a party once per month for those residents who had a birthday or name day in that month) which most residents look forward to and attend regularly. This celebration is generally regarded by the seniors as a big social event where they have the chance to meet other clients and family members who also attend the parties. It is important to mention that family members' presence at or engagement in events is a big plus for the quality of life in the residential home [7].

\section{CONCLUSION}

For seniors who, despite support from relatives and help from onsite services, can barely manage life in their own household, a stay in a residential retirement home with full services is a great relief. The research showed that seniors mentioned the certainty of care they would not have at home. It was also found that even seniors who managed to return to their natural environment would not consider this option. An underestimated advantage of institutional care is the social contact residents can enjoy in the retirement home. The homes offer a whole selection of leisure- time activities and can take the senior out of isolation (social exclusion) and exercise his/her mental faculties.

It can be generally noted that the evaluation of living conditions is an individual matter - everyone views their own living conditions subjectively, based on their own ladder of values. If we evaluate the living conditions of seniors in retirement homes, then we can say that the independence of these seniors can be retained for some time thanks to the environment and adequate help, but this is not a sustainable condition. Self-realisation is also fulfilled during leisure-time activities. The research showed that seniors living in retirement homes in both the Czech Republic and Austria are generally satisfied with nursing care, health care, the offer of leisure-time activities, the environment and their economic situation.

We can see from respondents' evaluation and the overall results that most people enter retirement homes due to health issues. The investigation also showed that almost half of the Czech respondents applied for the retirement home for some reason other than not being able to take care of themselves. A frequent cause is loneliness and the need to make space for younger family members.

It must be noted that the results apply only to one retirement home in the Czech Republic and one retirement home in Austria and cannot be generalised to all residential retirement homes in different countries. The authors therefore suggest carrying out further research with more respondents.

\section{REFERENCES}

[1] Šimák M. Sociální péče. In: Kahoun V, et al. Sociální zabezpečení: vybrané kapitoly, 1st ed. Praha: Triton, 2009; p. 354-355.

[2] Glosová D, et al. Bydlení pro seniory, 1st ed. Brno: ERA; 2006.

[3] Hrozenská $M$, et al. Sociálna práca so staršími lud'mi a jej teoreticko-praktické východiská, 1st ed. Martin: Osveta; 2008.

[4] Michalík J. Smluvní vztahy v sociálních službách, 1st ed. Olomouc: VCIZP; 2008.

[5] Innsbrucker Soziale Dienste [homepage on the Internet]. ( Innsbrucker Soziale Dienste $\mathrm{GmbH}$, Innrain 24, 6020 Innsbruck [cited 2012-Sept02]. Available from: http://www.isd.or.at

[6] Sýkorová D. Autonomie ve stárí. Kapitoly z gerontosociolgie, 1st ed. Praha: SLON; 2007.

[7] Pichaud C, Thareauová I. Soužití se staršími lidmi, 1st ed. Praha: Portál; 1998.

[8] Venglářová $M$. Problematické situace $v$ péči o seniory. Príručka pro zdravotnické a sociální pracovníky, 1st ed. Praha: Grada; 2007. 
[9] Jarošová, D. Péče o seniory, 1st ed. Ostrava: Ostravská univerzita v Ostravě, ZSF; 2006.

[10] Kalvach $Z$, Janečková $H$, Bureš $I$, et al. Dlouhodobá zdravotní a sociální ústavní péče. In: Kalvach Z, Zadák Z, Jirák R, et al. Geriatrie a gerontologie. 1st ed. Praha: Grada, 2004; p. 497.
[11] Klevetová D, Dlabalová, I. Motivační prvky při práci se seniory, 1st ed. Praha: Grada; 2008.

[12] Motlová L. Autonomie, nezávislost a uspokojování potřeb osob vyššího věku. Kontakt 2007; 2: 343-352. 